\title{
PENGELUARAN KONSUMSI MAHASISWA MUSLIM PADA ERA DIGITAL
}

\author{
Oleh \\ Dewi Wulansari'), Yulfan Arif Nurohman'2), Rina Sari Qurniawati3) \\ IAIN Surakarta ${ }^{1)}$ 2), STIE AMA Salatiga ${ }^{3)}$ \\ dewiwulan2130@gmail.com
}

\begin{abstract}
Abstrak
Penelitian ini bertujuan untuk mengetahui pengaruh pengetahuan, kemudahan e-money, keamanan e-money, dan religiusitas terhadap pengeluaran konsumsi mahasiswa muslim pada era digital. Data yang digunakan dalam penelitian ini berupa data primer dan data sekunder. Penelitian ini menggunakan metode kuantitatif yaitu dengan penyajian hasil penelitian dalam bentuk angka atau statistik guna menguji hipotesis. Populasi dalam penelitian ini merupakan mahasiswa muslim yang berada di Eks Karesidenan Surakarta. Data diperoleh dengan menggunakan kuesioner yang diberikan kepada mahasiswa muslim sejumlah 100 responden dengan menggunakan teknik purposive sampling. Hasil dari pengujian menyatakan bahwa pengetahuan dan religiusitas tidak berpengaruh terhadap pengeluaran konsumsi mahasiswa muslim, sedangkan kemudahan dan keamanan e-money berpengaruh terhadap pengeluaran konsumsi mahasiswa muslim.
\end{abstract}

Kata kunci: Kemudahan, Keamanan, Religiusitas, Pengeluaran konsumsi, E-money

\section{PENDAHULUAN}

Pertumbuhan ekonomi nasional didorong oleh tingkat konsumsi masyarakat. Berdasarkan data Badan Pusat Statistik (BPS) tahun 2018, pengeluaran konsumsi rumah tangga mencapai 8.269,8 triliun atau sebesar 55,7\% dari Produk Domestik Bruto (PDB). Pengeluaran konsumsi rumah tangga pada tahun 2018 terbilang besar dibandingkan tahun sebelumnya maupun setelahnya. Laju pertumbuhan konsumsi rumah tangga tahun 2018 sebesar 5,08\% year-on-year (yoy), sedangkan pada tahun 2017 pertumbuhan konsumsi rumah tangga sebesar 4,99\% yoy. Pertumbuhan konsumsi rumah tangga tahun 2019 lebih rendah dibandingkan tahun sebelumnya, yaitu sebesar 5,04\%.

Pengeluaran konsumsi yang mengalami fluktuasi pada masyarakat, diketahui bahwa terdapat suatu hal yang mempengaruhi konsumsi. Astuti (2018) menyatakan bahwa pengeluaran konsumsi yang dilakukan oleh rumah tangga berbeda-beda tergantung pada pendapatan dan kebutuhan. Pendapatan yang diterima digunakan untuk memenuhi kebutuhan makanan maupun non makanan dalam memenuhi kebutuhan 
sehari-hari. Sama halnya dengan rumah tangga, mahasiswa melakukan pengeluaran konsumsi untuk memenuhi kebutuhan hidup. Tindakan pengeluaran konsumsi mahasiswa merupakan nilai belanja yang dilakukan untuk membeli berbagai jenis kebutuhan. Secara garis besar kebutuhan mahasiswa dapat dibedakan menjadi dua, yaitu kebutuhan makanan dan non makanan (Perkasa, 2012). Kebutuhan makanan meliputi makanan pokok, protein hewani, sayur-sayuran, buah-buahan, jajanan, dan kelompok kebutuhan lain-lain yang diukur dalam kalori, sedangkan kebutuhan non makanan terdiri dari pembelian kuota internet, penyusunan tugas mata kuliah, transportasi dan skin care. Kebutuhan ini harus terpenuhi untuk memudahkan segala aktivitas yang dilakukan. Mahasiswa mengalokasikan pendapatan untuk memenuhi kebutuhan tersebut (Astuti, 2018).

Agama Islam melarang umatnya untuk hidup secara berlebihan, tetapi mengajarkan cara hidup yang proporsional. Gaya hidup hedonis atau perilaku konsumtif yang berlebihan dapat menyebabkan kerugian bagi diri sendiri maupun orang lain. Hal ini dapat menjadi permasalahan bagi mahasiswa muslim ketika merubah gaya hidup yang cenderung konsumtif karena kondisi lingkungan masyarakat maupun pergaulan. Salah satu aspek penting pada diri mahasiswa muslim yaitu religiusitas. Dimana religiusitas pada masing-masing orang berbeda, sehingga memiliki aktivitas ekonomi yang berbeda (Bawono, 2014). Sejak lama Bank Indonesia mencanangkan Gerakan Nasional Non Tunai (GNNT) lebih tepatnya pada tanggal 14 Agustus 2014. Gerakan ini ditujukan untuk meningkatkan kesadaran masyarakat terhadap penggunaan instrumen non tunai, sehingga berangsur-angsur terbentuk komunitas atau masyarakat yang lebih menggunakan instrument non tunai (Less Cash Society/LCS) khususnya dalam melakukan transaksi atas kegiatan ekonomi. Manfaat transaksi non tunai meliputi transaksi yang praktis tanpa membawa uang tunai, akses pembayaran lebih luas, keamanan, efisiensi rupiah, meningkatkan sirkulasi uang, dan mempermudah penghitungan (Kurniawan, 2018).

Pekembangan e-commerce mengubah gaya hidup masyarakat dalam sistem pembayaran (Tempo, 2019). E-money (Electronic money) atau uang elektornik menjadi pilihan untuk digunakan oleh masyarakat dalam melakukan transaksi. Berdasarkan data Bank Indonesia, jumlah uang elektronik beredar pada tahun 2019 mengalami kenaikan yang 
sangat signifikan. Pada bulan Januari, uang elektronik beredar sejumlah 575.264 instrumen, sedangkan pada bulan Desember mencapai 3.016.272 instrumen. Peningkatan jumlah uang elektronik beredar di Indonesia sudah terjadi sejak 10 tahun terakhir. Ramadani (2016) menyatakan bahwa pembayaran non tunai mempermudah mahasiswa dalam bertransaksi. Beliau juga menjelaskan bahwa penggunaan e-money menjadi salah satu pilihan dalam menilai tawaran gaya hidup untuk menjadi lebih efisien atau konsumtif. Adanya e-money mempengaruhi perilaku mahasiswa dalam konsumsi karena kemudahan dalam bertransaksi. hal tersebut sejalan dengan perkembangan e-commerce di Indonesia. Berdasarkan uraian diatas, maka peneliti tertarik untuk melakukan penelitian tentang pengeluaran konsumsi mahasiswa muslim pada era digital.

\section{LANDASAN TEORITIS DAN PENGEMBANGAN HIPOTESIS}

\section{Pengeluaran Konsumsi}

Samuelson (2000: 88) dalam Ramadhani (2016: 3) menjelaskan bahwa konsumsi sebagai kegiatan menghabiskan nilai guna barang dan jasa. Konsumsi mempunyai pengertian yang luas yaitu barang dan jasa akhir yang yang dibutuhkan untuk memenuhi kebutuhan manusia. Barang dan jasa akhir yang dimaksud adalah barang dan jasa yang sudah siap dikonsumsi oleh konsumen. Menurut Eugence A. Diulio dalam Tama (2014: 13) konsumsi terbagi 2 (dua) yakni konsumsi rutin dan konsumsi sementara.

Pengeluaran konsumsi mahasiswa merupakan nilai belanja yang dilakukan mahasiswa untuk membeli berbagai jenis kebutuhannya. Seperti dalam penelitian Perkasa (2012), secara garis besar kebutuhan mahasiswa dapat dikelompokkan dalam 2 kategori besar, yaitu kebutuhan makanan dan non makanan. Dengan demikian pada tingkat pendapatan tertentu, mahasiswa akan mengalokasikan pendapatannya untuk memenuhi kebutuhan tersebut (Astuti, 2018).

Seiring perkembangan zaman mengakibatkan kebutuhan masyarakat semakin kompleks, terutama mahasiswa. Hal tersebut berdampak pada pengeluaran konsumsi yang dilakukan oleh mahasiswa, dimana terjadi pergeseran dari konsumsi makanan ke konsumsi non makanan (Astuti, 2018). Dalam penelitian Mulyani (2015) menjelaskan teori Engel yang menyatakan bahwa pergeseran permintaan konsumsi non makanan lebih besar daripada konsumsi makanan, hal tersebut dipengaruhi oleh beberapa faktor yaitu 
tingkat pendapatan perkapita masyarakat, cita rasa atau selera konsumen terhadap barang, harga barang perlengkapan dan pengganti, serta harapan dari konsumen.

\section{Pengetahuan}

Pengetahuan (knowledge) merupakan suatu hal dalam diri manusia secara visual melalui pancaindra. Pengetahuan merupakan tingkat ketahuan seseorang melalui pengalaman yang dirasakan baik pada objek atau hal tertentu (Martono, 2012). Jayanti et al. (2011) mengatakan bahwa pengetahuan seseorang merupakan bagian yang penting dari perilaku konsumen, karena pengetahuan memengaruhi seseorang sebelum membeli suatu produk atau jasa. Jumlah yang dibeli, tempat membeli, dan waktu membeli sangat bergantung pada pengetahuan mahasiswa muslim mengenai produk yang akan dibeli. Pengetahuan konsumen juga dapat diartikan sebagai faktor utama penentu perilaku konsumen (Hayati et al. 2011). Adawiyah (2010) menjelaskan bahwa pengetahuan konsumen merupakan informasi yang dimiliki oleh konsumen mengenai berbagai macam produk dan jasa, serta pengetahuan lainnya yang terkait dengan produk dan jasa, serta mengetahui informasi tentang fungsinya. Menurut Wied Hary A, 1996 dalam Hendra AW (2008), Notoatmodjo, (1997), dan Singgih, (2008) faktor yang mempengaruhi pengetahuan meliputi:

\section{a. Pendidikan}

Tingkat pendidikan mempengaruhi daya pikir seseorang dalam menyerap informasi dan pengetahuan. Semakin tinggi pendidikan, maka semakin baik pula daya serap pemikiran yang dimiliki. Tingkat pendidikan yang tinggi pada diri mahasiswa memberikan sikap terbuka terhadap penggunaan teknologi terbaru seperti e-money.

b. Pengalaman

Peristiwa atau kejadian dimasa lalu mempengaruhi pengetahuan. Pengalaman berguna untuk mengevaluasi yang terjadi dimasa sekarang dengan melihat cara yang digunakan untuk memecahkan masalah dimasa lalu. Kendala dan risiko dalam bertransaksi menggunakan uang tunai pada masa lalu, memberikan peluang bagi mahasiswa menggunakan $e$-money.

c. Usia 
Daya pikir berubah seiring perkembangan usia. Ketika usia mencapai belasan tahun, maka daya pikir dan daya ingat sangat tajam. Akan tetapi ketika usia bertambah dan memasuki usia tua, tingkat daya ingat mengalami penurunan. Usia mudah lebih cepat beradaptasi dengan teknologi terbaru seperti $e$-money.

d. Informasi

Proses mendapatkan informasi dilakukan untuk kebutuhan akan pengetahuan. Informasi terbaru memberikan cara pandang, gaya hidup, dan sikap berbeda pada mahasiswa. Keterbaruan arus informasi mudah diperoleh dengan perkembangan teknologi informasi. E-money merupakan salah satu produk kemajuan teknologi informasi.

\section{H1 : Pengetahuan berpengaruh terhadap pengeluaran konsumsi mahasiswa muslim} Kemudahan e-money

Menurut Jogiyanto (2011: 115) Kemudahan didefinisikan sebagai sejauh mana seseorang percaya bahwa menggnakan suatu teknologi akan bebas dari usaha. Kemudahan penggunaan adalah mudah dipelajari, mudah dipahami, simpel dan mudah dalam pengoperasian. Menurut Iqbaria dalam Amijaya (2010: 14) kemudahan ini akan merdampak pada perilaku, yaitu semakin tinggi presepsi seseorang tentang kemudahan menggunakan teknologi, semakin tinggi pula tingkat pemanfaatan teknologi informasi. dapat diketahui bahwa kemudahan penggunaan merupakan suatu keyakinan tentang proses pengambilan keputusan.

Istiarni (2014: 19-20) menyatakan bahwa kemudahan dalam menggunakan teknologi dipengaruhi oleh beberapa faktor yaitu faktor dari teknologi itu sendiri, faktor dari reputasi, serta faktor dari mekanisme pendukung yang handal. Penggunaan $e$-money sangat mudah untuk dioperasikan dan memudahkan pemakai dalam bertransaksi. Ketika seseorang melakukan transaksi dengan menggunakan e-money akan langsung mengerti dan paham dalam mengaplikasikannya.

H2 : Kemudahan e-money berpengaruh terhadap pengeluaran konsumsi mahasiswa muslim 


\section{Keamanan e-money}

Menurut Simons dalam Ahmad dan Pambudi (2014: 5) keamanan informasi adalah bagaimana dapat mencegah suatu penipuan (cheating), mendeteksi adanya penipuan di sebuah sistem yang berbasis informasi, dimana informasinya tidak memiliki suatu arti fisik. Keamanan adalah suatu upaya untuk mengamankan aset informasi terhadap ancaman yang mungkin timbul, sehingga keamanan secara tidak langsung dapat menjamin kelangsungan bisnis dan mengurangi resiko-resiko yang terjadi.

Tingkat keamanan saat bertransaksi sering menjadi pertimbangan bagi konsumen sebelum menggunakan e-money. Keamanan memberikan kenyamanan pada pengguna (konsumen) dan meningkatkan kepercayaan konsumen (costumer trust), yang berujung kepada peningkatan penjualan (Pratama, 2015: 197). Paulus dkk (2005) menyatakan bahwa kebutuhan keamanan teknologi dapat dikategorikan menjadi privacy atau confidentiality, integrity, authentication, availability dan access control. Ketika keamanan menjadi telah dijamin, maka tingkat keyakinan dalam penggunaan semakin tinggi. Kerahasiaan data juga menjadi faktor yang penting yang tidak boleh tersebar dan diketahui oleh pihak lain yang tidak mempunyai kewenangan.

Casalo dkk dalam Ahmad dan Pambudi (2014: 5) menyatakan bahwa dari kacamata konsumen, keamanan dalam perbankan adalah suatu kemampuan untuk melindungi data atau informasi seseorang konsumen dari tindak penipuan dan pencurian dalam bisnis perbankan. Tingkat keamanan saat bertransaksi sering menjadi pertimbangkan bagi konsumen sebelum menggunakan e-money.

\section{H3 : Keamanan e-money berpengaruh terhadap pengeluaran konsumsi mahasiswa} muslim

\section{Religiusitas}

Menurut Jalaluddin (2010) religiusitas dapat didefinisikan sebagai suatu keadaan yang ada dalam diri individu yang mendorongnya untuk bertingkah laku sesuai dengan kadar ketaatannya terhadap agama. Menurut Nashori (2002) dalam Rois (2016: 23) religiusitas diartikan sebagai seberapa jauh pengetahuan, seberapa kokoh keyakinan, pelaksanaan ibadah dan kaidah, dan seberapa dalam penghayatan atas agama yang dianut. 
Bagi seorang muslim, religiusitas dapat diketahui dari seberapa jauh pengetahuan, keyakinan, pelaksanaan dan penghayatan atas agama Islam.

Religiusitas adalah sejauh mana individu berkomitmen kepada agama dan dengan agama itulah tercermin sikap dan perilaku individu (Ode, 2013). Menurut Nurcholis Majid dalam Asmaun (2011: 24), agama bukanlah sekedar tindakan-tindakan ritual seperti shalat dan membaca doa. Agama lebih dari itu, yaitu keseluruhan tingkah laku manusia yang terpuji, yang dilakukan demi memperoleh ridho dan perkenaan Allah. Terdapat lima dimensi religiusitas Glock dan Stark (1970) yaitu dimensi keyakinan, dimensi praktik agama, dimensi pengalaman, dimensi pengetahuan agama, dan dimensi pengamalan.

Menurut Bawono (2014) menyebutkan bahwa seorang muslim yang memiliki religiusitas yang tinggi, maka dia akan semakin mempertimbangkan prospek ke depan dengan lebih baik termasuk kehidupan dunia dan juga balasan yang diterima saat diakhirat. Oleh sebab itu pengeluaran konsumsi seorang muslim untuk memenuhi kebutuhan orang lain (sedekah) merupakan investasi dengan daya pikat tinggi. Investasi dalam bentuk sedekah dapat memberikan keuntungan dan berkah.

H4 : Religiusitas berpengaruh terhadap pengeluaran konsumsi mahasiswa muslim

\section{METODE PENELITIAN}

Tipe penelitian ini adalah tipe penelitian deskriptif yaitu tipe penelitian yang bertujuan untuk memberikan gambaran mengenai subjek penelitian berdasarkan data variabel yang diperoleh dari subjek yang diteliti dan dimaksudkan untuk pengujian hipotesis (Azwar, 2000:56). Populasi pada penelitian ini adalah mahasiwa muslim di Kota Surakarta dan sekitarnya. Metode pemilihan sampel (sampling) dalam penelitian ini dilakukan non probability sampling dengan tehnik purposive sampling. Adapun ukuran sampel yang akan digunakan, ditentukan dengan menggunakan rumus rumus Cochran atau Unkhown Populations belum diketahui secara pasti jumlah populasi mahasiswa muslim di Kota Surakarta dengan hasil 96, namun untuk mengatisipasi adanya kuesioner yang tidak memenuhi kriteria maka peneliti menyebarkan sebanyak 100 responden. 


\section{Tabel 1}

\section{Definisi Opersional Penelitian}

\begin{tabular}{|c|c|}
\hline Variabel & Indikator \\
\hline $\begin{array}{l}\text { Pengeluaran Konsumsi } \\
\text { Mahasiswa }\end{array}$ & $\begin{array}{l}\text { 1. Tren barang dan jasa } \\
\text { 2. Potongan harga } \\
\text { 3. Fasilitas yang ditawarkan } \\
\text { 4. Kebiasaan atau perilaku } \\
\text { 5. Promosi penjualan } \\
\text { 6. Desain produk }\end{array}$ \\
\hline Pengetahuan & $\begin{array}{l}\text { 1. Informasi produk } \\
\text { 2. Informasi relevan } \\
\text { 3. Keuntungan yang diperoleh } \\
\text { 4. Informasi yang mudah diterima } \\
\text { 5. Informasi yang mudah dimengerti } \\
\text { 6. Kecepatan dan ketepatan informasi }\end{array}$ \\
\hline Kemudahan $e$-money & $\begin{array}{l}\text { 1. Mudah digunakan dalam pengecekan saldo } \\
\text { 2. Mudah dipelajari dan dimengerti } \\
\text { 3. Kemudahan dalam transaksi } \\
\text { 4. Tidak memerlukan banyak usaha dan waktu }\end{array}$ \\
\hline Keamanan $e$-money & $\begin{array}{l}\text { 1. Jaminan keamanan data pribadi } \\
\text { 2. Keamanan dalam transaksi } \\
\text { 3. Mencegah terjadinya penipuan } \\
\text { 4. Dilidungi dari kerusakan dan pencurian }\end{array}$ \\
\hline Religiusitas & $\begin{array}{l}\text { 1. Kewajiban konsumsi makanan halal dan tayib } \\
\text { 2. Taat pada ajaran agama } \\
\text { 3. Kemanfaatan } \\
\text { 4. Tidak berlebih-lebihan } \\
\text { 5. Prioritas kebutuhan pokok } \\
\text { 6. Pemahaman keagamaan } \\
\text { 7. Pengamalan ajaran agama }\end{array}$ \\
\hline
\end{tabular}

\section{Analisis Data}

Analisa data dilakukan dengan menggunakan metode analisa kuantitatif yaitu dengan mengumpulkan, mengolah, dan menginterpretasikan data yang diperoleh sehingga memberi keterangan yang benar dan lengkap untuk pemecahan masalah yang dihadapi. Metode analisis data yang digunakan dalam penelitian ini adalah model regresi 
sederhana dengan menggunakan bantuan software SPSS for window 12.5. Jenis pengujian yang dapat dipakai dalam penelitian ini, yaitu uji asumsi klasik dan pengujian hipotesis.

Regresi linear merupakan suatu metode analisis statistik yang mempelajari pola hubungan antara dua atau lebih variabel. Pada kenyataan sehari-hari sering dijumpai sebuah kejadian dipengaruhi oleh lebih dari satu variabel. Analisis regresi linier berganda memberikan kemudahan bagi pengguna untuk memasukkan lebih dari satu variabel prediktor hingga $\mathrm{p}$-variabel prediktor dimana banyaknya $\mathrm{p}$ kurang dari jumlah observasi (n). Regresi linier berganda, digunakan untuk mengetahui independen variabel mana saja (Pengetahuan, Kemudahan e-money, Keamanan e-money serta Religiusitas) yang merupakan prediktor variabel dependen (Pengeluaran Konsumsi Mahasiswa Muslim), dengan persamaan : Y $=\alpha+\beta 1 \mathrm{X} 1+\beta 2 \mathrm{X} 2+\beta 3 \mathrm{X} 3+\beta 4 \mathrm{X} 4+\varepsilon$. Dimana; Y adalah Pengeluaran Konsumsi; $\alpha$ : Konstanta; $\beta_{1}$ : Koefisien regresi; $\mathrm{X}_{1}$ : Pengetahuan; $\mathrm{X}_{2}$ : Kemudahan; $\mathrm{X}_{3}$ : Keamanan ; $\mathrm{X}_{4}$ : Religiusitas

\section{HASIL DAN PEMBAHASAN}

Dalam penelitian ini, kuesioner diberikan kepada 105 responden dan kuesioner yang diterima kembali sejumlah 100 kuesioner. Setelah melalui analisis data, ditemukan bahwa data yang memenuhi untuk dianalisis lebih lanjut adalah sebanyak 100 responden. Dari 100 data, responden pria berjumlah 66 orang (66\%) dan responden wanita berjumlah 34orang (34\%).

Pengujian validitas dilakukan dengan Uji validitas dilakukan dengan membandingkan nilai $\mathrm{r}$ hitung (correlated item-total correlations) dengan nilai $\mathrm{r}$ tabel. Jika nilai $\mathrm{r}$ hitung > $\mathrm{r}$ tabel dan bernilai positif maka pertanyaan tersebut dikatakan valid (Ghozali, 2005:11). Hasil pengujian validitas menunjukkan semua item pernyataan valid. Selanjutnya, pengujian reliabilitas setiap konstruk dilakukan dengan menggunakan koefisien Cronbach's. Semua variabel yang ada dalam penelitian ini yaitu, pengetahuan, kemudahan, keamanan, religiusitas, dan pengeluaran konsumsi menunjukkan hasil di atas 0,6. Hal ini mengindikasikan bahwa semua responden menjawab semua pertanyaan dalam kuesioner dengan konsisten. 
Tabel 2

Uji Reliabilitas

\begin{tabular}{|l|c|c|c|}
\hline \multicolumn{1}{|c|}{ Variabel } & $\begin{array}{c}\text { Cronbach } \\
\text { Alpha }\end{array}$ & $\begin{array}{c}\text { Alpha } \\
\text { Pembanding }\end{array}$ & Keterangan \\
\hline Pengetahuan $\left(\mathrm{X}_{1}\right)$ & 0,764 & 0,6 & Reliabel \\
\hline Kemudahan e-money $\left(\mathrm{X}_{2}\right)$ & 0,672 & 0,6 & Reliabel \\
\hline Keamanan -money $\left(\mathrm{X}_{3}\right)$ & 0,707 & 0,6 & Reliabel \\
\hline Religiusitas $(\mathrm{X} 4)$ & 0,883 & 0,6 & Reliabel \\
\hline $\begin{array}{l}\text { Pengeluaran Konsumsi } \\
\text { Mahasiswa Muslim (Y) }\end{array}$ & 0,782 & 0,6 & Reliabel \\
\hline
\end{tabular}

$R=0,935 R^{2}=0,874 F_{\text {Hitung }}=164.004$

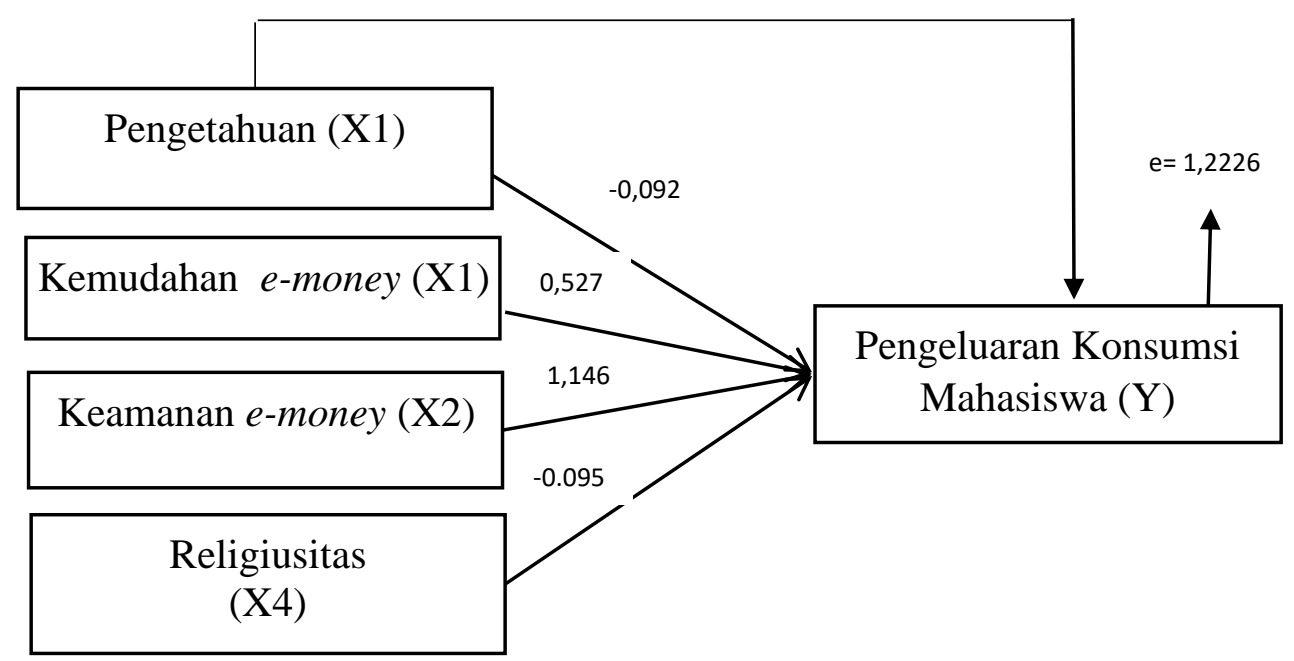

Gambar 1

Hasil Analisis Model Riset

Tabel 3

Analisa Hasil Uji Hipotesis

\begin{tabular}{|c|l|c|c|}
\hline \multicolumn{2}{|c|}{ Hipotesis } & Sig.* & Hasil \\
\hline H1 & $\begin{array}{l}\text { Pengetahuan berpengaruh terhadap } \\
\text { pengeluaran konsumsi mahasiswa muslim }\end{array}$ & 0.042 & Ditolak \\
\hline H2 & $\begin{array}{l}\text { Kemudahan e-money berpengaruh terhadap } \\
\text { pengeluaran konsumsi mahasiswa muslim }\end{array}$ & 0.000 & Diterima \\
\hline H3 & $\begin{array}{l}\text { Keamanan e-money berpengaruh terhadap } \\
\text { pengeluaran konsumsi mahasiswa muslim }\end{array}$ & 0.000 & Diterima \\
\hline H4 & Religiusitas berpengaruh terhadap & 0.126 & Ditolak \\
\hline
\end{tabular}


pengeluaran konsumsi mahasiswa muslim

Catatan:* Nilai signifikansi pada 0,005

\section{PEMBAHASAN}

Dari pengujian hipotesis 1 diperoleh hasil bahwa tidak terdapat pengaruh pengetahuan terhadap pengeluaran konsumsi mahasiswa. Informasi tentang produk dan penggunaan e-money sangat mudah didapatkan. Proses mendapatkan informasi tentang produk dan penggunaan $e$-money tidak memerlukan tingkat pengetahuan yang tinggi pada diri mahasiswa muslim. Seperti penelitian yang dilakukan oleh Idris Habsari Candraditya (2013) bahwa pengetahuan yang dimiliki oleh mahasiswa tidak mempengaruhi minat dalam mengguanakan e-money.

Berbeda dengan hipotesis 1, hipotesis 2 pada penelitian ini terdukung. Hasil pengujian hipotesis menunjukkan bahwa kemudahan e-money berpengaruh terhadap pengeluaran konsumsi mahasiswa. Usia dari mahasiswa aktif saat ini termasuk ke dalam generasi $\mathrm{Y}$ dan $\mathrm{Z}$ dimana mereka termasuk dari generasi yang sudah mengenal teknologi dengan baik. Kemudahan dalam menggunakan teknologi didasari bahwa dari usia mereka masih muda sudah terbiasa dan berpengalaman menggunakan gadget. Penggunaan kartu ATM dan uang elektronik sangat mudah untuk dioperasionalkan dan memudahkan pemakai dalam penggunaannya

Pengujian hipotesis 3 yang menyatakan bahwa keamanan e-money berpengaruh terhadap pengeluaran konsumsi mahasiswa didapatkan hasil yang terbukti. Mahasiswa merasa penggunaan e-money memberikan adanya perlindungan yang akurat terhadap teknologi informasi guna untuk menghindarkan dari ancaman pihak-pihak yang tidak bertanggungjawab. Sehingga mahasiswa sebagai pengguna uang elektronik merasa aman saat melakukan transaksi. Pratama (2015: 197) menyatakan bahwa keamanan dapat memberikan kenyamanan pada pengguna (konsumen). Keamanan yang didapatkan dalam penggunaan e-money meliputi terhindar dari risiko mendapatkan uang palsu, tidak perlu membawa uang dengan jumlah yang besar, dan perlindungan menggunakan teknologi.

Hasil dari hipotesis ke 4 yang menyatakan bahwa religiusitias berpengaruh terhadap pengeluaran konsumsi mahasiswa tidak terbukti. Sifat dari mahasiswa saat ini cenderung ke arah konsumtif apalagi pembayaran dari barang yang dibeli dipermudah dengan 
adanya e-money. Kebutuhan memenuhi gaya hidup dan tren kekinian membuat mahasiswa berperilaku konsumtif. Pemahaman tentang agama yang semakin tinggi tidak sertamerta menggunakannya dalam bersikap, membuat pertimbangan dan memutuskan untuk melakukan pembelian. Kebutuhan non makanan menjadi tambahan yang harus dipenuhi oleh mahasiswa saat ini.

\section{KESIMPULAN}

Penelitian ini membahas tentang pengaruh penggunaan, kemudahan, keamanan, penggunaan e-money, dan religiusitas terhadap pengeluran konsumsi mahasiswa. Berdasarkan uraian sebelumnya, maka peneliti memberikan kesimpulan sebagai berikut:

1. Pengujian pertama menghasilkan bahwa variabel pengetahuan tidak berpengaruh signifikan terhadap pengeluaran konsumsi mahasiswa muslim. Hal ini disebabkan karena gaya hidup dan tren kekinian yang harus dipenuhi oleh mahasiswa dengan mengesampingkan pengetahuan yang dimiliki.

2. Pengujian kedua menghasilkan bahwa variabel kemudahan berpengaruh signifikan terhadap pengeluaran konsumsi mahasiswa. Hal tersebut disebabkan karena mahasiswa saat ini merupakan gerenerasi Y dan Z yang hidup bersamaan dengan pertumbuhan teknologi informasi, sehingga dalam penggunaan $e$-money tidak menemukan kendala.

3. Pengujian ketiga menghasilkan bahwa keamanan berpengaruh signifikan terhadap pengeluaran konsumsi mahasiswa. Penggunaan e-money oleh mahasiswa untuk menghindari kerugian yang tidak diharapkan ketika menggunakan uang tunai. Risiko penggunaan e-money lebih rendah dibandingkan penggunaan uang tunai.

4. Pengujian keempat menghasilkan bahwa religiusitas tidak berpengaruh signifikan terhadap pengeluaran konsumsi mahasiswa. Gaya hidup mahasiswa yang mengikuti perkembangan zaman membuat pengeluaran konsumsi meningkat dalam memenuhi kebutuhan kekinian dan mengikuti tren, serta mengesampingkan pemahaman agama yang dimiliki. 


\section{DAFTAR PUSTAKA}

Asmaun, S. (2011). Religiusitas Perguruan Tinggi: Potret Tradisi Keagamaan di Perguruan Tinggi Islam. Malang: UIN Maliki Press.

Astuti, T. P. (2018). Analisis Faktor-Faktor yang Mempengaruhi Pola Konsumsi Mahasiswa. Skripsi, UIN Syarif Hidayatullah, Jakarta.

Bawono, A. (2014). Kontribusi Religiusitas dalam Rasionalitas Konsumsi Rumah Tangga Muslim. Inferensi, Jurnal Penelitian Sosial Keagamaan, Vol.8 No. 2, 287-308.

Carolin, C. (1999). Hubungan Antara Religiusitas dengan Tingkat Penalaran Moral pada Pelajar Madrasah Mu'alimat Muhammadiyah Yogyakarta, Skripsi tidak diterbitkan, Yogyakarta

Fatmasari, D. (2019). Use of E-Money and Debit Cards in Student Consumption Behavior. E3S Web of Conferences 125.

Glock \& Stark (1970). American Piety: The Nature of Religious Commitment. London: University of California Press.

Habsari, Candraditya Idris (2013). Analisis Penggunaan Uang Elektronik (Studi Kasus Pada Mahasiswa Pengguna Produk Flazz BCA di Fakultas Ekonomika dan Bisnis Universitas Diponegoro). DIPONEGORO JOURNAL OF MANAGEMENT Volume 2, Nomor 3.

Hidayati, Siti dkk. (2006). Kajian Operasional E-Money. Jakarta : Bank Indonesia.

Jogiyanto, H.M. (2011). Sistem Informasi Keperilakuan. Yogyakarta: Andi

Jusmaliani, N. H. (2009). Religiosity Aspect in Consumer Behaviour: Determinants of Halal Meat Consumption. Asean Marketing Journal, Vol. 1 No. 2.

Khair, M. R. (2019). Analisis Penggunaan Alat Pembayaran Menggunakan Kartu (AMPK) dan E-Money Terhadap Konsumsi Masyarakat Di Banda Aceh. Jurnal Ilmiah Mahasiswa Ekonomi Islam, Vol. 1 No. 1, 19-36.

Kloter, Philip. (2005). Manajemen Pemasaran. Edisi Kesebelas, Jakarta: Indeks Kelompok Gramedia.

Mulyani, S. (2015). Pola Konsumsi Non Makanan Mahasiswa Program Studi Pendidikan Ekonomi Universitas Negeri Yogyakarta. Skripsi, Universitas Negeri Yogyakarta, Yogyakarta.

Nashori, F. (2002). Agenda Psikologi Islam. Yogyakarta: Pustaka Pelajar.

Nur, A. D. (2010). Dampak Penggunaan Kartu Anjungan Tunai Mandiri (ATM) Terhadap Pola Konsumsi Remaja. Skripsi, Fakultas Ilmu Sosial dan Ilmu Politik Universitas Sebelas Maret Surakarta, Surakarta.

Ode, M. L. (2013). Politik Tiga Wajah. Jakarta: Yayasan Pustaka Obor Indonesia.

Pamungkas, G. T. (2018). Pengaruh Perilaku Konsumen Terhadap Pengguna E-Money (Studi Kasus Minimarket Indomaret Kec. Binjai, Kota Binjai. Skripsi, Universitas Negeri Sumatera Utara, Medan.

Perkasa, A. A. (2012). Faktor-Faktor yang Mempengaruhi Pola Konsumsi Mahasiswa UNHAS. Skripsi tidak diterbitkan, Makassar. 
Ramadhani, L. (2016). Pengaruh Penggunaan Kartu Debit dan Uang Elektronik Terhadap Pengeluaran Konsumsi Mahasiswa. JESP, Vol. 8, No. 1, 1-8.

Rois, E. L. (2016). Pengaruh Religiusitas, Norma Subyektif dan perceived Behavior Control Terhadap Niat Membeli Produk Makanan Ringan Berlabel Halal. Universitas Negeri Yogyakarata 